\title{
PEWARISAN KETAHANAN MELON (Cucumis melo L.) KULTIVAR MELODI GAMA 3 TERHADAP Kyuri green mottle mosaic virus
}

\section{RESISTANCE'S INHERITANCE TO Kyuri green mottle mosaic virus IN MELON (Cucumis melo L.) MELODI GAMA 3 CULTIVAR}

\author{
Budi Setiadi Daryono ${ }^{1)}$ \& Fauziatul Fitriyah ${ }^{1)^{*}}$ \\ ${ }^{1)}$ Fakultas Biologi, Universitas Gadjah Mada \\ Jln. Teknika Selatan, Sekip Utara, Sleman, Yogyakarta 55281 \\ *Penulis untuk korespondensi.E-mail:fauziatul.fitriyah@mail.ugm.ac.id
}

\begin{abstract}
Melon (Cucumis melo L.) belongs to Cucurbitaceae. Melon has high potential to be developed as main horticultural product in Indonesia. Melon is one of important foreign exchange and is the fifth biggest horticulture commodity in Indonesia. One of the problems in melon farming is mosaic disease caused by Kyuri green mottle mosaic virus (KGMMV). $K G M M V$ infection reduces the quality and the amount of melon production. Melon farmers suffered a significant financial loss. Melodi Gama 3 (MG3) is a high yielding melon cultivar from the Genetics Laboratory, Faculty of Biology, Universitas Gadjah Mada. The use of genetically resistant melon cultivar has beneficial outcome for agriculture sector. The aim of this research was to study the resistance's inherintance to KGMMV in MG3 melon cultivar. Two cultivars of MG3, $M G 3 \mid 5$ and $M G 3 \mid 8$, were cultivated in the greenhouse. MAI, Glamour, Ladika, and Action melon cultivars were used as references. Resistance of KGMMV was analyzed by symptom observation and serological detection using Double Antibody Sandwich Enzyme Linked Immunosorbent Assay (DAS-ELISA). DAS-ELISA result analyzed further to establish resistance category. Description to melon cultivar phenotype variation was done. The result of this research indicates that MG3 melon cultivar is tolerant to KGMMV. The decrease of MG3 optical density was directly related with the lowering of KGMMV symptoms. The character of tolerance to KGMMV was inherited from Melodi Gama 1 (MG1) cultivar.
\end{abstract}

Keywords: DAS-ELISA, KGMMV, melon

\section{INTISARI}

Melon (Cucumis melo L.) merupakan tanaman buah yang tergolong dalam familia Cucurbitaceae. Tanaman melon berpotensi untuk dikembangkan sebagai produk unggulan hortikultura di Indonesia. Tanaman melon juga merupakan salah satu penghasil devisa penting Indonesia dan menempati urutan ke-5 dari kelompok hortikultura. Salah satu kendala yang sering dihadapi oleh petani melon adalah penyakit mosaik yang disebabkan oleh Kyuri green mottle mosaic virus (KGMMV). Infeksi KGMMV pada pertanian melon mengakibatkan penurunan kualitas dan kuantitas hasil, sehingga petani mengalami kerugian ekonomi yang cukup berarti. Melodi Gama 3 (MG3) merupakan kultivar melon unggul hasil rakitan Laboratorium Genetika, Fakultas Biologi, Universitas Gadjah Mada. Penggunaan kultivar melon yang tahan terhadap infeksi KGMMV secara genetis merupakan alternatif yang sangat bermanfaat dalam bidang pertanian. Penelitian ini dilakukan untuk mengetahui pewarisan ketahanan MG3 terhadap infeksi KGMMV. Melon kultivar MG3, ditumbuhkan di greenhouse. Sebagai pembanding digunakan melon kultivar yang umum ditanam petani, yaitu MAI, Glamour, Ladika, dan Action. Kelima kultivar melon tersebut diinokulasi dengan KGMMV. Parameter ketahanan KGMMV yang digunakan adalah segregasi gejala dan uji serologis dengan Double Antibody Sandwich Enzyme Linked Immunosorbent Assay (DASELISA). Hasil DAS-ELISA selanjutnya dianalisis untuk mengetahui kategori ketahanannya. Dilakukan pula deskripsi pada variasi fenotip kultivar melon yang ditanam. Hasil penelitian ini menunjukkan bahwa tanaman melon kultivar Melodi Gama 3 memiliki sifat toleransi terhadap infeksi KGMMV. Toleransi ditunjukkan dengan nilai optical density (OD) yang menurun seiring dengan penurunan gejala infeksi KGMMV. Sifat ketahanan terhadap KGMMV diwariskan dari kultivar Melodi Gama 1 (MG1).

Kata kunci: DAS-ELISA, KGMMV, melon

\section{PENGANTAR}

Melon (Cucumis melo L.) merupakan tanaman buah yang tergolong dalam familia Cucurbitaceae. Melon mulai masuk dan dibudidayakan di Indonesia pada tahun 1970. Daya pikat buah melon bagi konsumen terletak pada cita rasanya yang enak, manis, beraroma wangi dan khas (Delahaut \& Newenhouse, 1998).
Tanaman melon berpotensi untuk dikembangkan sebagai produk unggulan hortikultura di Indonesia. Tanaman melon juga merupakan salah satu penghasil devisa penting Indonesia dan menempati urutan ke-5 dari kelompok hortikultura. Pada tahun 2002, Indonesia mengekspor buah melon 334,11 ton ke Jepang, Korea, Hongkong, dan Singapura. Tahun 2009, produksi buah melon nasional adalah 85.861 ton dengan luas 
lahan 3.245 ha. Ekspor dan produksi buah melon di Indonesia semakin meningkat dari tahun ke tahun (Anonim, 2010).

Daryono et al. (2005) melaporkan pertama kali penemuan Kyuri green mottle mosaic virus (KGMMV) menginfeksi tanaman melon di Indonesia. Tanaman yang diinfeksi KGMMV menunjukkan berbagai gejala (symptom) antara lain deformasi daun, mosaik, mottle, dan buah yang keras. Infeksi KGMMV pada pertanian melon mengakibatkan penurunan kualitas dan kuantitas hasil, sehingga petani mengalami kerugian ekonomi yang cukup berarti (Tan et al., 2000).

Melodi Gama 3 (MG3) merupakan kultivar melon unggul hasil rakitan Laboratorium Genetika, Fakultas Biologi, Universitas Gadjah Mada. MG3 merupakan hasil persilangan antara melon kultivar Melodi Gama 1 (MG1) dan Ladika. Salah satu keunggulan MG3 terdapat pada karakteristik buah, seperti warna, aroma, net, dan tingkat kemanisan (Daryono et al., 2012). Penggunaan kultivar melon yang tahan terhadap infeksi KGMMV secara genetis merupakan alternatif yang sangat bermanfaat dalam bidang pertanian. Oleh karena itu, penelitian ini dilakukan untuk mengetahui pewarisan ketahanan MG3 sebagai kultivar melon unggul terhadap infeksi KGMMV.

\section{BAHAN DAN METODE}

Penelitian dilaksanakan pada bulan FebruariAgustus 2013. Penanaman dan inokulasi dilakukan di green house Jurusan Ilmu Tanah Fakultas Pertanian Universitas Gadjah Mada. Uji serologis dilakukan di Laboratorium Genetika dan FALITMA (Fasilitas Penelitian Bersama) Fakultas Biologi, Universitas Gadjah Mada.

Bahan yang dibutuhkan dalam penelitian ini meliputi bahan untuk penanaman melon dan bahan untuk pengujian serologis. Bahan yang digunakan untuk penanaman adalah benih tanaman melon kultivar MG3, Action, Glamour, Ladika, serta MAI dari Laboratorium Genetika Fakultas Biologi Universitas Gadjah Mada, alkohol 70\%, akuades, dan media tanam. Inokulasi tanaman dengan virus membutuhkan bahanbahan berupa inokulum berupa daun tanaman melon kultivar ladika yang telah positif terinfeksi virus KGMMV, karborandum (600 mesh), dan bufer fosfat $0,1 \mathrm{M}$. Bahan untuk pengujian serologis meliputi serum antibodi KGMMV dan konjugat, akuades steril, PBST wash buffer, Phosphat buffer, PNP substrat buffer, PNP substrate tablets, dan general extract buffer.

\section{Penanaman Benih Melon}

Benih melon kultivar MG3, Action, Glamour, Ladika, serta MAI dikecambahkan pada petri dish.
Perkecambahan diamati setiap hari. Keberhasilan perkecambahan ditandai dengan munculnya akar primer dan daun pertama. Benih melon yang telah berkecambah dipindahkan ke dalam pot plastik yang telah diisi tanah berhumus dan abu sekam dengan perbandingan $3: 1$. Benih yang telah berumur 10-14 hari sudah siap dipindah ke dalam pot besar.

\section{Inokulasi KGMMV}

Daun tanaman melon yang telah berumur 10-15 hari setelah persemaian ditaburi carborundum $(600$ mesh). Tanaman kontrol tidak ditaburi carborundum. Inokulum KGMMV disiapkan dan ditimbang sebanyak 0,1 gram daun dimasukkan ke dalam mortar ditambah dengan $1 \mathrm{ml}$ bufer fosfat dan digerus agar tercampur sempurna. Setelah beberapa saat dari penaburan carborundum, daun diolesi dengan inokulum. Daun dibiarkan selama 3-5 menit kemudian dicuci dengan air mengalir.

\section{Skoring Gejala}

Gejala yang terlihat setelah melon diinokulasi dengan KGMMV diberi skor seperti pada Tabel 1.

Tabel 1. Indeks skor uji sifat ketahanan melon kultivar MG3 terhadap infeksi KGMMV (Norman et al., 1997)

\begin{tabular}{cll}
\hline Skor & Gejala yang teramati & Keterangan \\
\hline 0 & $0 \%$ & Tidak ada gejala \\
1 & $1 \%-10 \%$ & Sangat rendah \\
2 & $10 \%-35 \%$ & Rendah \\
3 & $35 \%-65 \%$ & Sedang \\
4 & $65 \%-90 \%$ & Tinggi \\
5 & $90 \%-100 \%$ & Sangat tinggi $/$ mati \\
\hline
\end{tabular}

Pengamatan gejala dilakukan selama 4 minggu sejak melon diinokulasi dengan virus. Selanjutnya melon diklasifikasikan menjadi tahan dan tidak tahan berdasarkan insidensi gejala dan intensitasnya.

Insidensi gejala dihitung dengan rumus:

Insidensi $=\frac{\sum \text { tanaman yang sakit }}{\sum \text { tanaman yang sehat }} \times 100 \%$

Intensitas penyakit dihitung dengan rumus:

Intensitas $=\frac{\sum(\mathrm{n} \times \mathrm{v})}{\mathrm{Z} \times \mathrm{N}} \times 100 \%$

Keterangan:

$\mathrm{n}$ : Jumlah tanaman terinfeksi

$\mathrm{v}$ : Persentase gejala

$\mathrm{Z}$ : Nilai skala tertinggi

$\mathrm{N}$ : Jumlah daun total 


\section{Pengujian Serologis Tanaman Melon Hasil Inokulasi KGMMV}

Prosedur DAS-ELISA yang dilakukan berdasarkan protokol pada serum antibodi (Agdia, USA). Coating dengan antibodi yang spesifik dengan antigen dilakukan dengan mengencerkan antibodi KGMMV dalam coating buffer dengan perbandingan 1:200. Campuran dipipet sebanyak $100 \mu 1 /$ sumuran dan diinkubasi selama $3,5-4$ jam pada suhu $37^{\circ} \mathrm{C}$. Selanjutnya, 0.1 gram sampel daun yang terinfeksi dihaluskan dan dilarutkan dalam $1 \mathrm{ml}$ general extract buffer. Seluruh sampel disentrifugasi pada $3000 \mathrm{rpm}$ selama 5 menit. Supernatan yang terbentuk merupakan antigen dalam pengujian ini. Sebanyak $100 \mu \mathrm{l}$ antigen dipipet ke dalam sumuran kemudian diinkubasi pada refrigerator pada suhu $4^{\circ} \mathrm{C}$ selama 18 jam. Selanjutnya, sebanyak $100 \mu l$ antibodi konjugat dalam buffer fosfat (1:200) dipipet ke dalam masing-masing sumuran dan diinkubasi selama 3 jam dengan suhu $37^{\circ} \mathrm{C}$. Microtitre plate kemudian diinkubasi dengan substrat-enzim (PNP tablet dalam PNP buffer pada konsentrasi 1 $\mathrm{mg} / \mathrm{ml}$ ) sebanyak $150 \mu \mathrm{l} /$ sumuran pada suhu kamar selama 30-45 menit. Selanjutnya dilakukan pembacaan absorbansi dengan ELISA reader pada panjang gelombang $405 \mathrm{~nm}$, sehingga diperoleh nilai absorbansi hasil uji ELISA. Sampel dinyatakan positif terinfeksi KGMMV apabila nilai absorbansinya mencapai tiga kali lebih besar dari nilai absorbansi tanaman sehat. Pengujian serologis dilakukan untuk mengamati konsentrasi virus yang terdapat pada tanaman melon yang telah diinokulasikan virus KGMMV. Intensitas warna yang bervariasi menunjukkan konsentrasi virus yang terkandung dalam cairan tersebut. Semakin tinggi absorbansi cahaya pada cairan maka semakin tinggi pula konsentrasi virus di dalamnya.

\section{Analisis Data}

Parameter ketahanan KGMMV yang digunakan adalah segregasi gejala dan uji serologis dengan double antibody sandwich enzyme linked immunosorbent assay (DAS-ELISA). Hasil DAS-ELISA selanjutnya dianalisis dengan uji chi-square, kemudian dilakukan deskripsi pada variasi fenotip kultivar melon yang ditanam.

\section{HASIL DAN PEMBAHASAN}

\section{Gejala pada Melon Hasil Inokulasi KGMMV}

Gejala lokal infeksi KGMMV pada tanaman melon yang diuji terjadi antara 3-5 hari setelah inokulasi (HSI). Semua tanaman melon kultivar MG3 dan Glamour yang diinokulasikan KGMMV telah menunjukkan gejala sistemik infeksi virus pada 7 HSI. Tanaman melon kultivar MAI, Ladika, dan Action baru menunjukkan gejala sistemik pada 11 HSI. Infeksi KGMMV pada kultivar melon yang diuji menunjukkan gejala lokal berupa klorotik pada daun yang diinokulasi virus dilanjutkan dengan gejala sistemik berupa penyebaran virus ke bagian tanaman lain melalui pembuluh tapis menuju daerah titik tumbuh (meristem apikal).

Berdasarkan Gambar 1 dapat diketahui bahwa intensitas penyakit KGMMV paling tinggi terlihat pada tanaman melon kultivar Ladika. Sedangkan, tanaman melon kultivar MG3 $\mid 8$ adalah kultivar dengan persentase intensitas penyakit yang paling rendah. Tanaman melon kultivar MG3|5 masih memiliki intensitas yang lebih rendah dibandingkan dengan kultivar Glamour dan Action.

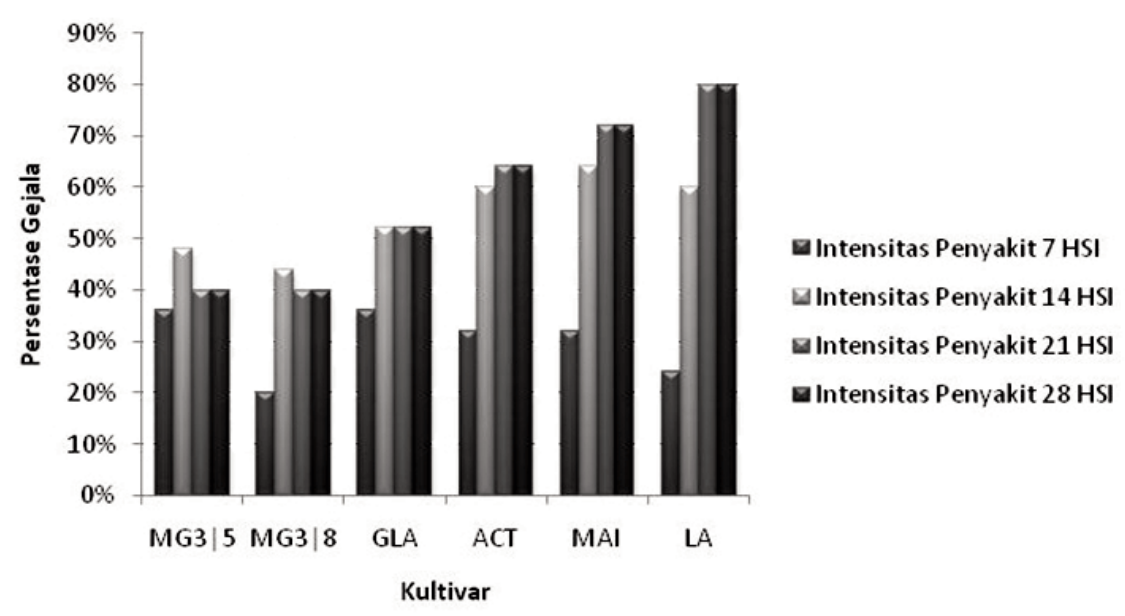

Gambar 1. Histogram intensitas penyakit pada tanaman uji 


\section{Pengujian Serologi Tanaman Melon Hasil Inokulasi KGMMV}

Konsentrasi virus pada tanaman melon yang diuji bervariasi pada setiap hari setelah pengamatan (Gambar 2). Pada 14 HSI konsentrasi virus tertinggi terdapat pada kultivar Ladika, kemudian MAI, MAG3|5, Action, Glamour, dan yang paling rendah adalah kultivar MG3|8. Pada $21 \mathrm{HSI}$, konsentrasi virus pada kultivar MAG3|5, MG3|8, dan Glamour mengalami peningkatan, sedangkan pada kultivar Action, Ladika, dan MAI mengalami penurunan. Penurunan konsentrasi virus pada kultivar MAG3|5, MG3|8, dan Glamour baru terjadi pada 28 HSI. Dengan demikian, terlihat bahwa pola yang dialami oleh setiap kultivar tanaman melon yang diuji tersebut sama, yaitu mengalami kenaikan konsentrasi setelah inokulasi, kemudian mulai penurunan. Kenaikan yang dialami oleh tiga kultivar pertama terjadi setelah $21 \mathrm{HSI}$, sedangkan pada Kultivar Action, Ladika, dan MAI terjadi segera setelah 14 HSI.

\section{Pewarisan Ketahanan Tanaman Melon terhadap KGMMV}

Data pengujian Chi-Square terhadap segregasi ketahanan KGMMV hasil skoring pada generasi $\mathrm{F}_{1}$ dan $\mathrm{F}_{2}$ tanaman melon kultivar MG3 disajikan pada Tabel 2. Berdasarkan Tabel 2 dapat diketahui bahwa critical value pada ó 5\% adalah 3,841 (untuk $\mathrm{dF}=1$ ), dan karena nilai $\mathrm{X}^{2}$ hitung $>\mathrm{X}^{2}$ tabel.

Pengujian pewarisan sifat ketahanan terhadap Kyuri green mottle mosaic virus (KGMMV) dilakukan terhadap tanaman melon kultivar Melodi Gama 3, MAI, Glamour, Ladika, dan Action. Terdapat dua macam kultivar MG3 yang digunakan, yaitu MG3 dengan indukan MG1 (MG3|8) dan MG3 dengan indukan Ladika (MG3|5). Insidensi gejala pada kelima kultivar mencapai 100\% yang artinya seluruh tanaman uji menunjukkan gejala infeksi KGMMV.

Dua kultivar MG3 menunjukkan pola gejala yang sama. Tanaman melon kultivar MG3 $\mid 5$ dan MG3 $\mid 8$ mempunyai pola gejala yang menurun dari minggu ke-2 sampai minggu ke-4 setelah inokulasi. Saat inokulasi, virion KGMMV masuk ke dalam sitoplasma dan menyebabkan gejala lokal pada 3-5 HSI. Setelah berreplikasi, virus terdistribusi ke bagian lain tanaman yang menyebabkan munculnya gejala pada bagian tanaman yang lebih muda, sehingga muncul gejala sistemik pada 7 HSI. Pada lebih dari 28 HSI, beberapa tanaman uji pada kultivar MG3|5 dan MG3|8 bahkan sudah tidak menunjukkan bercak kuning atau jika masih ada maka jumlahnya jauh lebih sedikit dibandingkan ketika awal setelah inokulasi.

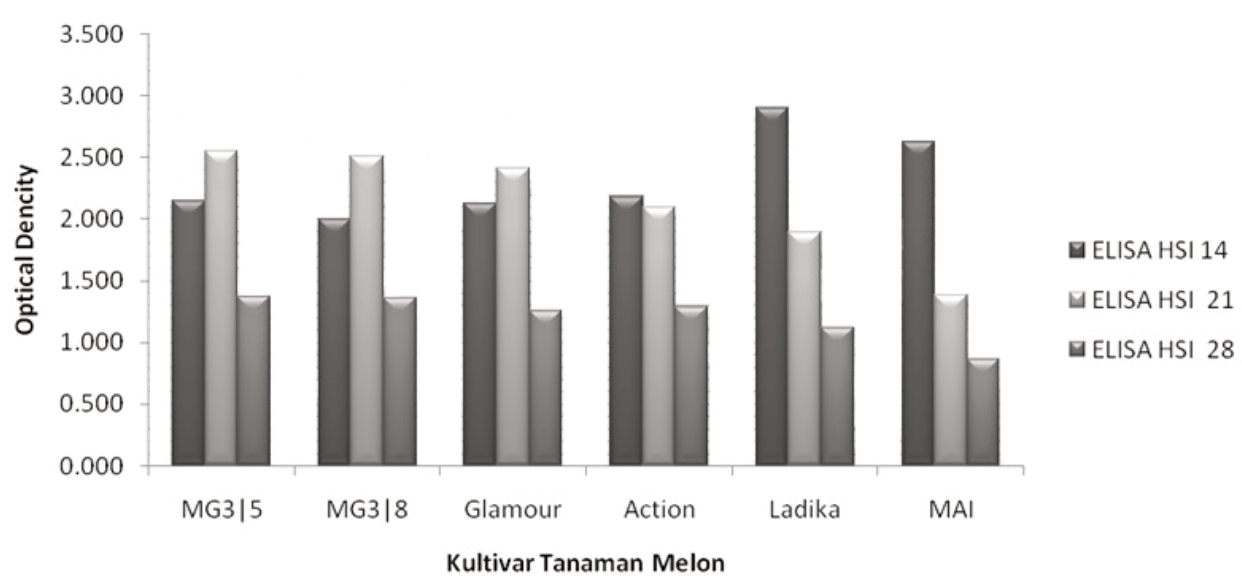

Gambar 2. Histogram optical density pada kultivar melon yang diuji

Tabel 2. Uji $X^{2}$ (Chi-Square) terhadap segregasi ketahanan KGMMV hasil skoring pada generasi F1 dan F2 tanaman melon kultivar MG3

\begin{tabular}{lrrrccc}
\hline Generasi & \multicolumn{3}{c}{ Jumlah Tanaman } & $\mathrm{X}^{2}$ hitung & $\mathrm{X}^{2}$ tabel $(0.05)$ & Keterangan \\
\cline { 2 - 4 } & Total & \multicolumn{2}{c}{ Tahan } & Rentan & & \\
\hline MG1 & 5 & 5 & 0 & & & \\
Ladika & 5 & 0 & 5 & \multirow{2}{*}{19,253} & 3,841 & $\mathrm{X}^{2}$ hitung $>\mathrm{X}^{2}$ tabel \\
MG3 (F1) & 5 & 5 & 0 & & & \\
MG3 (F2) & 100 & 94 & 6 & & & \\
\hline
\end{tabular}


Gejala yang muncul pada tanaman melon kultivar Glamour, Action, Ladika, dan MAI memiliki pola yang seragam, yaitu membentuk pola sigmoid. Kultivar Glamour, dan MAI memiliki gejala yang terus meningkat sampai 28 HSI. Gejala infeksi yang dialami oleh kultivar Ladika menunjukkan peningkatan sampai $21 \mathrm{HSI}$

Berdasarkan Gambar 1 dan 2, terlihat perbedaan pola yang terbentuk pada skor gejala dan konsentrasi virus. Penurunan konsentrasi virus pada tanaman melon kultivar Glamour, Action, Ladika, dan MAI ternyata tidak disertai dengan penurunan tingkat gejala yang diderita. Tanaman melon kultivar MG3|5 dan MG3|8 menunjukkan gejala yang terus menurun sejak 14 HSI, meskipun konsentrasi virus dalam dua kultivar tersebut masih lebih tinggi dibandingkan dengan keempat kultivar yang lain.

Agrios (1996) menyebutkan bahwa asam nukleat yang terdapat di dalam virus ternyata belum cukup mampu untuk menyebabkan terjadinya gejala penyakit pada tumbuhan inangnya. Disebutkan pula bahwa, beberapa tumbuhan yang mengandung konsentrasi virus yang lebih tinggi menunjukkan gejala yang lebih lemah atau tidak menunjukkan gejala sama sekali dibandingkan dengan tumbuhan lain yang konsentrasi virusnya lebih rendah. Hal tersebut dapat terjadi karena penyakit yang disebabkan oleh virus pada tumbuhan bukan hanya disebabkan kekurangan nutrisi karena digunakan untuk sintesis virus, tetapi pengaruh virus secara tidak langsung lebih berpengaruh terhadap metabolisme inangnya.

Pengaruh sekunder virus terhadap tumbuhan inang dapat terjadi melalui sintesis protein baru oleh tumbuhan yang disebabkan oleh virus, beberapa di antaranya adalah zat yang aktif secara biologis dan dapat mengganggu metabolisme sel inang yang normal. Tingkat atau jenis gangguan metabolik tersebut mungkin dapat ditoleransi oleh tumbuhan sehingga tidak menyebabkan gejala, sedangkan pada jenis tumbuhan lain justru dapat memperburuk perkembangan gejala yang terjadi (Agrios, 1996).

Dengan demikian, tanaman melon kultivar MG3|5 dan MG3|8, meskipun mengandung virus dalam konsentrasi yang lebih tinggi dibandingkan kultivar lainnya, mampu menoleransi pengaruh sekunder yang diberikan oleh virus, sehingga dapat memperbaiki gejala yang muncul di awal infeksi. Agrios (1996) juga menjelaskan bahwa jika tumbuhan dengan pola tersebut mampu bertahan hidup pada permulaan fase infeksi, maka gejala akan cenderung melemah dan pada bagian tumbuhan yang berkembang setelah-nya dapat sembuh sebagian atau tidak menunjukkan gejala sama sekali.
Mehrotra (1983) menjelaskan bahwa, tanaman tidak memiliki mekanisme seperti antibodi untuk melawan infeksi virus. Penyakit yang disebabkan oleh virus tersebut ternyata akan tetap diderita oleh tanaman inang dan tidak akan hilang sampai tanaman mati. Wingard (1928) dalam Mehrotra (1983) melaporkan keberadaan mekanisme pemulihan (recovery) gejala pada tanaman tembakau yang terinfeksi Tobacco ring spot virus. Penelitian selanjutnya menjelaskan bahwa pemulihan tersebut karena penyakit tersebut memiliki dua fase dalam infeksi, yaitu akut dan kronis. Tanaman yang sedang mengalami pemulihan tetap mengandung virus.

Dengan demikian, dapat diketahui bahwa tanaman melon yang diuji mengalami penurunan konsentrasi virus kemungkinan karena dua fase infeksi yang dimiliki oleh KGMMV, yaitu fase akut dengan konsentrasi virus sangat tinggi, dan fase kronis dengan konsentrasi virus mulai berkurang. Tanaman melon kultivar MG3|5 dan MG3|8 mampu menoleransi infeksi tersebut dengan menunjukkan symptom recovery seiring dengan berkurangnya konsentrasi virus. Kultivar lain tidak mampu melakukan pemulihan dari gejala yang diderita meskipun fase infeksi virus sudah berganti menjadi kronis. Kultivar tersebut tidak dapat menoleransi gejala sekunder yang disebabkan oleh virus.

Tanaman melon kultivar MG3 merupakan kultivar melon unggul hasil rakitan Laboratorium Genetika, Fakultas Biologi, Universitas Gadjah Mada. Kultivar MG3 dihasilkan dari persilangan dengan kultivar lain, salah satunya PI 371795. Alaydrus (2008) telah melaporkan bahwa kultivar moyang dari MG3, yaitu PI 371795 tahan terhadap infeksi KGMMV dan gen ketahanan terhadap KGMMV dikendalikan oleh gen tunggal dominan. Oleh sebab itu, berbagai kultivar lain yang dihasilkan dari persilangan dengan PI 371795 juga mempunyai sifat ketahanan terhadap KGMMV, antara lain kultivar TC-4 dan MG1. Dua kultivar tersebut juga merupakan kultivar indukan dari MG3.

Berdasarkan hasil penelitian, diketahui bahwa kultivar Ladika menunjukkan sifat ketidaktahanan atau rentan terhadap infeksi KGMMV yang paling tinggi dibandingkan kultivar lain yang diuji. Selain itu, kultivar MG3|8 yang memiliki indukan MG1 memiliki tingkat toleransi yang lebih tinggi dibandingkan dengan MG3|5 yang memiliki indukan Ladika. Sehingga, dapat dikatakan bahwa sifat toleransi lebih tinggi terdapat pada kultivar dengan indukan yang juga toleran atau tahan terhadap infeksi KGMMV.

Berdasarkan Tabel 2 dapat diketahui bahwa critical value pada ó $5 \%$ adalah 3,841 (untuk $\mathrm{dF}=1$ ), dan 
karena nilai $\mathrm{X}^{2}$ hitung $>\mathrm{X}^{2}$ tabel, maka hasil yang diobservasi tersebut tidak sesuai dengan perbandingan Mendel $3: 1$. Sehingga, dapat diketahui bahwa pewarisan sifat ketahanan terhadap infeksi KGMMV terhadap tanaman melon kultivar MG3 tidak sama dengan pola pewarisannya pada kultivar MG1, pola pewarisan monohibrid dominansi penuh. Meskipun demikian, sifat ketahanan terhadap KGMMV pada tanaman melon kultivar MG3 diwariskan dari indukannya MG1 melalui pola lain.

Gray dan Moyer (1993) menjelaskan bahwa sifat ketahanan suatu tanaman terhadap infeksi virus dapat melalui berbagai mekanisme. Salah satunya adalah dengan memutus distribusi virus dari sel ke sel. Jenis ketahanan tersebut dapat dideteksi dengan menggunakan DAS-ELISA. Tanaman yang membawa gen ketahanan tersebut mengalami gejala infeksi virus pada awal inokulasi, namun dilanjutkan dengan adanya symptom recovery. Recovery muncul pertama kali pada jaringan yang muda karena tanaman membatasi distribusi virus dari jaringan tua yang terinfeksi ke jaringan yang sedang tumbuh. Proses recovery juga terlihat pada pola infeksi KGMMV terhadap tanaman melon kultivar MG3 (Gambar 1). Pola infeksi tersebut menunjukkan gen yang terlibat di dalamnya kemungkinan adalah poligenik (Gray \& Moyer, 1993).

\section{KESIMPULAN}

Berdasarkan penelitian yang dilakukan dapat disimpulkan bahwa tanaman melon kultivar Melodi Gama 3 memiliki sifat toleran terhadap infeksi KGMMV. Sifat toleran tanaman melon kultivar MG3 terhadap KGMMV diwariskan dari indukan kultivar Melodi Gama 1.

\section{UCAPAN TERIMA KASIH}

Penelitian ini didanai melalui Hibah Penelitian prioritas Nasional MP3EI Nomor LPPM-UGM/1259/LIT/2014 tahun 2012-2014 dan Dana BOPTN Fakultas Biologi Universitas Gadjah Mada tahun anggaran 2013.

\section{DAFTAR PUSTAKA}

Agrios, G.N. 1996. Ilmu Penyakit Tumbuhan. Edisi ketiga. Gadjah Mada University Press, Yogyakarta. $713 \mathrm{p}$.
Anonim. 2010. Data Mengenai Hasil Pertanian Di Indonesia. http://dds.bps.go.id/tab_sub/view.php? 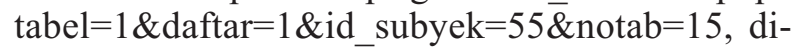 akses tanggal 7/11/13.

Alaydrus, Y. 2008. Pemuliaan dan Pewarisan Sifat Ketahanan terhadap Kyuri green mottle mosaic virus (KGMMV) pada Melon (Cucumis melo L.). Tesis. Fakultas Biologi Universitas Gadjah Mada, Yogyakarta. 124 p.

Daryono, B.S., S.D. Hayuningtyas, \& S.D. Maryanto. 2012. Perakitan Melon (Cucumis melo L.) Kultivar Melodi Gama 3 dalam Rangka Penguatan Industri Pertanian Nasional, hlm. 245-256. Dalam E. Soesilowati, S. Oktavilia, A.B. Setiawan, \& N. Rahayu (ed.), Prosiding Seminar Nasional Integrasi Kebijakan dan Penguatan Industri Nasional Menuju Percepatan dan Perluasan Ekonomi Indonesia. Jurusan Ekonomi Pembangunan, Fakultas Ekonomi, Universitas Negeri Semarang, Semarang.

Daryono, B.S., S.S. Somowiyarjo \& K.T. Natsuaki. 2005. Biological and Molecular Characterization of Melon-Infecting Kyuri Green Mottle Mosaic Virus in Indonesia. Journal of Phytopathology 153: 588595.

Delahaut, K.A. \& A.C. Newenhouse. 1998. Growing Pumpkins and Other Vine Crops in Wisconsin: A Guide for Fresh-Market Grower. Produced by cooperative extension publishing, University of Wisconsin-Extension, Wisconsin. 22 p.

Gray, S.M. \& J.W. Moyer. 1993. Resistance in Cucumis melo to Watermelon mosaic virus that Reduces Disease Severity and Disease Incidence, p. 196-216. In M.M. Kyle (ed.). Resistance to Viral Diseases of Vegetables: Genetics and Breeding. Timber Press, Portland, Ore.

Mehrotra, R.S. 1983. Plant Pathology. McGrawHill Publishing Company Limited, India. 847 p.

Norman, D.J., R.J. Henny, \& J.M.F. Yuen. 1997. Disease Resistance in Twenty Dieffenbachia Cultivars. HortScience 32: 709-710.

Tan, S. H., M. Nishiguchi, M. Murata, \& F. Motoyoshi. 2000. The Genome Structure of Kyuri green mottle mosaic tobamovirus and its Comparison with That of Cucumber green mottle mosaic tobamovirus. Archives of Virology 145: 1067-1079. 